\title{
Winners and Losers in the World Sugar Market due to Trade Liberalisation in the EU Sugar Sector
}

\author{
Ellen Huan-Niemi ${ }^{1}$ and Leena Kerkelä ${ }^{2}$ \\ ${ }^{1}$ MTT Taloustutkimus, Luutnantintie 13, FI-00410 Helsinki \\ ${ }^{2}$ Valtion taloudellinen tutkimuskeskus (VATT), Arkadiankatu 7, FI-00100 Helsinki
}

The ongoing trade negotiations, unilateral trade concessions and obligations under the World Trade Organization (WTO) are pushing the EU sugar regime to undertake reforms. These reforms will alter the positions of developing countries in the global sugar markets. Gradual changes within the tariff rate quotas in the EU sugar regime would have a very marginal impact on the flow of sugar exports to the EU and world sugar markets as well. The simulation results showed that the scheduled changes in tariff rate quotas and transition period are stalling the impacts of tariff liberalisation granted by the Everything But Arms (EBA) concession. Small concessions will not threaten the EU internal market, but total liberalisation of sugar imports from the least developed countries (LDCs) will be a major threat to the EU sugar regime. Conversely, the EU would gain from the liberalisation scenarios in welfare terms due to cheaper imports of sugar. The current regime limits sugar imports from all developing countries or some efficient producers, if the cost data is a right estimate of the potential supply response from developing countries. The supply responses, which strongly affect the outcomes, are dependent on both the nature of substitution for sugar as well as on the efficiency of sugar production in different countries. The LDCs would be the major winners under the EBA concession supported by the unchanged EU sugar regime, but if the current regime is entirely liberalised, much of the gains are diluted due to the deterioration in the terms of trade and a few efficient sugar producers would be the winners. The multi-region and multi-sector general equilibrium framework (GTAP model) is used for this analysis.

The full liberalisation of the EU sugar regime and the abolition of the preferential treatment in the EU sugar regime would change the position of the countries as winners or losers. The assumptions on the production and export possibilities of the sugar producing countries and the homogenous nature of sugar would create more losers than winners. For some of the losers, the loss of sugar exports could seriously damage their fragile economy. Therefore, the abolition or loss of preferential treatment is an important issue and hotly debated around the world.

Trade preferences have the potential of helping developing countries to promote self-sustained economic development and can substitute transfers in the form of direct financial assistance from developed countries to poor developing countries. The EU has maintained this development perspective by granting preferential access to the highly protected and subsidised EU sugar market with prices significantly above the world market prices. In the short run, any sudden changes in the EU regime and trade policies may cause severe problems for the poor currently employed in the export-oriented sugar industry of the developing countries. Compensation is needed for these affected people because of the adjustment costs due to the changes in trade policies. In the long run, the sustainable export performance and economic development based on the comparative advantage of the developing countries should be the final objective. Though, the livelihood of the poor must be protected against sudden changes in trade policies in the effort to achieve the Millennium Development Goals.

Keywords: EU sugar regime, WTO, market access, tariffs, preferential trade agreements, ACP countries, least developed countries, general equilibrium framework (GTAP model). 


\section{Introduction}

Highly protected markets of the developed countries are extremely lucrative markets for developing countries with preferential market access, especially when the domestic market price in the developed countries is significantly higher than the world market price. A good example is the EU sugar sector. The EU is a net exporter of sugar partly due to over production and preferential market access granted to developing countries, thus making the EU a leading exporter and importer in the world sugar market (Table 1). The EU's leading position in the world sugar market is a result of domestic policy and not because of having a comparative advantage in sugar production. Current policy plans, where trade preferences may be substantially eroded or even removed, may harm current beneficiaries by weakening their export performance and thus causing further difficulties in the process of integration into the world economy. Full liberalisation of the EU sugar sector will most probably improve the market access for sugar exports of both developing and developed countries, but which countries are the winners is still an open question.

Table 1. Major sugar producers, importers and exporters: 2000-02 average (in raw sugar equivalents)

\begin{tabular}{|c|c|c|c|c|c|}
\hline \multicolumn{2}{|l|}{ Main Producers } & \multicolumn{2}{|l|}{ Main Importers } & \multicolumn{2}{|l|}{ Main Exporters } \\
\hline Country/regions & Mil.tonnes & Country/region & Mil.tonnes & Country/region & Mil.tonnes \\
\hline Brazil & 21.6 & Russia & 5.0 & Brazil & 11.9 \\
\hline India & 20.7 & European Union & 1.9 & European Union & 6.2 \\
\hline European Union & 17.3 & Indonesia & 1.8 & Thailand & 4.3 \\
\hline China & 9.2 & Japan & 1.6 & Australia & 3.6 \\
\hline United States & 7.6 & Malaysia & 1.5 & Cuba & 2.6 \\
\hline Thailand & 6.5 & Korea & 1.5 & India & 1.5 \\
\hline Mexico & 5.2 & Nigeria & 1.5 & South Africa & 1.3 \\
\hline Australia & 5.1 & United States & 1.4 & Columbia & 1.3 \\
\hline Pakistan & 3.9 & Canada & 1.2 & Guatemala & 1.1 \\
\hline Cuba & 3.2 & Algeria & 1.2 & Mauritius & 0.5 \\
\hline All other & 39.5 & All other & 27.1 & All other & 13.6 \\
\hline World & 139.8 & World & 45.7 & World & 47.9 \\
\hline
\end{tabular}

Source: F.O. Lichts International Sugar and Sweetener Report

The multi-region and multi-sector general equilibrium model (Global Trade Analysis Project - GTAP model) is used for studying the changes in the global sugar markets. The GTAP model is also used by Frandsen et al. (2003) to analyse the production quotas under the EU sugar regime and the impact of EU sugar policy reform on the EU-15 member states. Partial equilibrium models are commonly used in the analysis of sugar policies. These models are applied in studies done by Devadoss and Kropf (1996), Borrell and Pearce (1999), Poonyth et al. (2000), and OECD (2003). These papers study the impacts of multilateral trade liberalisation in the global sugar markets either gradually or fully. The results from these papers have shown the effects of multilateral trade liberalisation on the EU sugar sector. As a complement to these papers, this study is focusing on the unilateral trade liberalisation of the EU sugar sector.

\section{Methodology}

The GTAP model and database are standard tools for analysis in the changing world of commodity markets. The standard model assumes competitive environment where consumers and firms take prices of goods and factors as given. Different trade policies as well as domestic policies are implemented to the model and database as price wedges between different prices, e.g. the domestic and world market price. Exogenous changes like trade liberalisation affect the relative prices between regions and commodities and the behaviour of consumers and producers within economies to produce a new equilibrium to the economy. Different regions in the model are combined by bilateral trade flows in each commodity and the demand structure in foreign trade differentiates between 
commodities imported from different sources. This enables the equilibrium to remain in nonspecialized pattern of trade where substitution possibilities play a central role.

The GTAP Data Base 5.4 consists of 78 regions and 57 industries and can be aggregated to larger entities. In the simulations, the regions have been aggregated to 20 new regions by outlining the least developed countries (LDCs) and African, Caribbean, \& Pacific (ACP) countries as detailed as possible. The following are regions defined as ACP countries: Guyana/ Rest of South America (XSM), Central America \& Caribbean (XCM), Zimbabwe (ZWE), Mauritius/Other Southern Africa (XSF), and Swaziland/Rest of South African Customs Union (XSC). The regions defined as the LDCs are Mozambique (MOZ), Malawi (MWI), Tanzania (TZA), Uganda (UGA), Zambia (ZMB), Rest of SubSaharan Africa (XSS), Bangladesh (BGD) and Nepal/Rest of South Asia (XSA). Many regions are originally aggregates of several countries, but exports of preferential sugar to the EU could come only from a single country from the region. For example, Rest of South African Customs Union (XSC) consists of Swaziland, South Africa, Namibia, and Lesotho, but Swaziland is the only country exporting preferential sugar to the EU from this region. The regions are labelled according to the preferential sugar exporters to the EU market. Thus, the region XSC (Rest of South African Customs Union) as a whole is only representing Swaziland.

The industries are aggregated into four main groups: sugar, agriculture, manufacturing and services. Sugar is seen as a single commodity consisting of raw and white sugar. The base year for the database is 1997. For some trade figures, the values are not compatible with the current situation. Instead of concentrating on the exact absolute levels, the relative changes in export levels are analysed.

Two different approaches are used to estimate the winners and losers in the changes made to the EU sugar trade preferences. The first approach is to look at the changes in trade flows into the EU. Trade flows give an intuitive picture of the effects on the producer side of the economy, especially when most of the production is allocated to exports. The second approach to indicate the winners and losers is an aggregate measure in regional welfare evaluated in US dollars. This regional equivalent variation (EV) is a traditional valuation for the consumption basket within the economies. The dollar values of current preferences are compared to these welfare gains /losses due to changing trade flows under different liberalisation scenarios. Often the change in gross domestic product (GDP) is used as an aggregate measure of gains or losses, but it is not applicable in this case because the data includes aggregates of several countries.

The simulations are implemented in steps in order to capture the time span of the changes made to the EU sugar regime. First, changes are made within the tariff quota system of the trade preferences applied in the EU sugar regime. Second, the EU sugar regime is liberalised for a set of countries only - the LDCs first and later both the LDCs and ACP countries. Finally, the EU sugar regime is liberalised for all countries in the world.

\section{Results}

The unilateral liberalisation of the EU sugar sector is divided into four scenarios: EBA scenario, EBA \& EPA scenario, PERFECT scenario and REAL scenario. Table 2 shows the sugar trade flows to the expanded EU (EU-15 and EU-12 together) from different countries/regions. If tariff liberalisation in the EU sugar regime is limited to the LDCs only under the EBA scenario, these countries would benefit the most. Duty and quota free market access for the LDCs would be at the expense of the ACP countries that do not belong to the LDCs category and other low cost sugar producing countries. However, it is assumed that all the LDCs can fully adapt their sugar production to the world market price without guaranteed market access or price. Also, necessary investments are available for these countries to expand sugar production in order to increase exports to the EU market. Infrastructure improvement is especially needed in land-locked countries to facilitate the increase of sugar exports to the EU.

The EBA \& EPA scenario, which includes tariff liberalisation for both the LDCs and ACP countries, would benefit the ACP countries the most. Countries not included in the tariff liberalisation process are the main losers in this scenario. Though, it is assumed that the ACP countries could fully adapt their sugar production to the world market price and extend their current sugar production significantly. This outcome may be unrealistic because many of the ACP beneficiaries are high cost 
producers. These high cost sugar producers may not be able to adjust their rigid production structures and dramatically increase their exports to the EU at world market price.

In the PERFECT scenario, where the EU sugar regime is liberalised for all countries, the greatest beneficiaries would be those countries whose current market access to EU have been restricted the most. The EU's protection is at the expense of other large sugar producers or exporters like India, Brazil, Thailand and Australia. In this scenario, the ACP countries are major winners as well because the model assumes that the ACP countries could fully adapt their sugar production to the world market price and extend their current sugar production significantly. Hence, the assumption here is that the ACP countries' current market share in the EU is the base for the expansion in market share after market liberalisation in the EU sugar regime. However, the current market share of the ACP countries is guaranteed by tariff rate quotas and the price paid is much higher than the world market price. It is doubtful that the ACP countries can compete at world market prices without guaranteed market access due to preferential treatment.

In the REAL scenario, the EU sugar regime is liberalised for all countries, but the potential supply responses are based on the estimations of the countries' production costs for sugar. Countries with the lowest productions costs, but also with the highest tariff, are assumed to have the best market access when the EU sugar market is fully liberalised. The benefits would accrue to a few countries like Brazil, Zimbabwe, Zambia, etc. Most of the current sugar exporters from the ACP countries like Mauritius may disappear from the EU market even though Mauritius has a strong presence in the EU sugar market due to the current preferential treatment granted by the EU. Most of the LDCs are losers under this scenario. The ultimate winner would be Brazil with almost $95 \%$ of the total sugar exports to the EU from all countries in the world.

Table 2. Sugar trade flows to the EU (USD million)

\begin{tabular}{|l|c|c|c|c|}
\hline \multirow{2}{*}{ Regions } & \multicolumn{2}{|c|}{ Partial Liberalisation } & \multicolumn{2}{c|}{ Full Liberalisation } \\
\cline { 2 - 5 } & EBA & EBA \& EPA & PERFECT & REAL* $^{*}$ \\
\hline & -22 & & & \\
Guyana & 937 & 579 & -16 \\
Central America/Caribbean & -50 & 4715 & 2043 & -46 \\
Zimbabwe & -2 & 269 & 142 & 395 \\
Mauritius & -75 & 1898 & 1263 & -65 \\
Swaziland & -20 & 2077 & 921 & 64 \\
India & -11 & -11 & 1167 & 0 \\
Mozambique & 54 & 10 & 4 & 2 \\
Malawi & 287 & 106 & 56 & 37 \\
Tanzania & 562 & 153 & 71 & -6 \\
Uganda & 25 & 3 & 1 & 0 \\
Zambia & 256 & 104 & 62 & 217 \\
Sub-Saharan Africa & 5027 & 913 & 369 & -5 \\
Bangladesh & 19 & 2 & 1 & 0 \\
Nepal & 2912 & 853 & 373 & -9 \\
Brazil & -1 & -2 & 1939 & 11034 \\
Thailand & 0 & 0 & 347 & 43 \\
Australia & 0 & 0 & 487 & 58 \\
Rest of the World & -43 & -48 & 2879 & -25 \\
\hline & & & & \\
Total exports to the EU & 8918 & 11979 & 12703 & 11677 \\
\hline
\end{tabular}

* production cost data is incorporated into the shocks for REAL simulations

Table 3 and 4 will also depict the winners and losers of EU's protection and tariff liberalisation for sugar. In all the tariff liberalisation scenarios, EU sugar exports would disappear from the global sugar markets. In terms of trade, the greatest loser would be the EU. EU sugar production would decrease the most (83\%) under the PERFECT scenario with a total value of USD 31.5 billion. Even under the EBA scenario, EU sugar production would decrease by over USD 22 billion. Production of sugar in 
the EU would still decrease by $64 \%$ even though tariff liberalisation in the EU sugar regime is limited to the LDCs only.

Table 3. Changes in the production of sugar (in percent)

\begin{tabular}{|c|c|c|c|c|}
\hline \multirow[t]{2}{*}{ Regions } & \multicolumn{2}{|c|}{ Partial Liberalisation } & \multicolumn{2}{|c|}{ Full Liberalisation } \\
\hline & EBA & EBA \& EPA & PERFECT & $\mathrm{REAL}^{*}$ \\
\hline EU-15 & -63.84 & -81.34 & -83.31 & -71.79 \\
\hline EU-12 & -22.93 & -53.35 & -66.54 & -55.5 \\
\hline Guyana & -10.17 & 675.6 & 419.21 & -5.31 \\
\hline Central America/Caribbean & 5.03 & 173.17 & 79.71 & 8.20 \\
\hline Zimbabwe & 3.48 & 207.2 & 111.45 & 305.38 \\
\hline Mauritius & -41.22 & 1191.84 & 798.11 & -32.44 \\
\hline Swaziland & 2.71 & 282.02 & 129.04 & 17.88 \\
\hline India & 0.51 & 0.23 & 5.85 & 0.23 \\
\hline Mozambique & 236.36 & 60.14 & 35.87 & 28.43 \\
\hline Malawi & 2124.61 & 781.53 & 416.53 & 272.27 \\
\hline Tanzania & 131.07 & 36.5 & 17.56 & -0.47 \\
\hline Uganda & 21.73 & 3.80 & 2.03 & 1.40 \\
\hline Zambia & 890.71 & 362.66 & 215.94 & 753.84 \\
\hline Sub-Saharan Africa & 201.07 & 41.12 & 20.69 & 10.02 \\
\hline Bangladesh & 2.53 & 0.51 & 0.59 & 0.75 \\
\hline Nepal & 74.47 & 22.47 & 10.44 & 0.43 \\
\hline Brazil & 3.35 & 3.74 & 18.57 & 90.30 \\
\hline Thailand & 6.25 & 7.68 & 20.82 & 8.48 \\
\hline Australia & 5.22 & 8.38 & 36.85 & 11.07 \\
\hline Rest of the World & 2.11 & 3.18 & 8.73 & 2.93 \\
\hline
\end{tabular}

* production cost data is incorporated into the shocks for REAL simulations

Table 4. Changes in the production of sugar (in USD million)

\begin{tabular}{|c|c|c|c|c|}
\hline \multirow[t]{2}{*}{ Regions } & \multicolumn{2}{|c|}{ Partial Liberalisation } & \multicolumn{2}{|c|}{ Full Liberalisation } \\
\hline & EBA & EBA \& EPA & PERFECT & REAL* \\
\hline EU-15 & -20638 & -26297 & -26933 & -23208 \\
\hline EU-12 & -1585 & -3687 & -4598 & -3835 \\
\hline Guyana & -15 & 1027 & 637 & -8 \\
\hline Central America/Caribbean & 141 & 4840 & 2228 & 229 \\
\hline Zimbabwe & 7 & 389 & 209 & 573 \\
\hline Mauritius & -90 & 2613 & 1750 & -71 \\
\hline Swaziland & 24 & 2474 & 1132 & 157 \\
\hline India & 105 & 47 & 1217 & 49 \\
\hline Mozambique & 49 & 13 & 8 & 6 \\
\hline Malawi & 312 & 115 & 61 & 40 \\
\hline Tanzania & 595 & 166 & 80 & -2 \\
\hline Uganda & 35 & 6 & 3 & 2 \\
\hline Zambia & 398 & 162 & 96 & 337 \\
\hline Sub-Saharan Africa & 6435 & 1316 & 662 & 321 \\
\hline Bangladesh & 30 & 6 & 7 & 9 \\
\hline Nepal & 2790 & 842 & 391 & 16 \\
\hline Brazil & 528 & 589 & 2924 & 14223 \\
\hline Thailand & 157 & 193 & 524 & 213 \\
\hline Australia & 110 & 176 & 775 & 233 \\
\hline Rest of the World & 1316 & 1983 & 5446 & 1829 \\
\hline
\end{tabular}

* production cost data is incorporated into the shocks for REAL simulations 
On the other hand, the EU overall would gain from the liberalisation scenarios in welfare terms due to cheaper imports of sugar. The welfare effects are opposite compared to the trade effects in the case of the EU. Though, Guyana would be one of the countries that would lose both in welfare and trade terms due to the loss of preferences. An aggregate measure in regional welfare evaluated in US dollars is collected in Table 5 to show the winners and losers in welfare terms.

The losers under the REAL scenario are Guyana, Mauritius, India, Tanzania, Uganda, SubSaharan Africa, Bangladesh, Nepal and Rest of the World. For some of the countries/regions, there would be positive welfare gains even though the export flows are negatives. This is because the loss in export flows could be compensated by a more efficient resource allocation, i.e. Central America/Caribbean. The connection between welfare and trade can be illustrated by comparing the trade and welfare values. The LDCs would gain in terms of market access due to the EBA concession, but much of the gains are diluted due to the deterioration in the terms of trade under the total liberalisation scenario.

Table 5. The aggregate welfare effects

\begin{tabular}{|l|c|c|c|c|}
\hline \multirow{2}{*}{ Regions } & \multicolumn{2}{|c|}{ Partial Liberalisation } & \multicolumn{2}{|c|}{ Full Liberalisation } \\
\cline { 2 - 5 } & EBA & EBA \& EPA & PERFECT & REAL \\
\hline EU-15 & 1582 & 4051 & 5119 & 2886 \\
EU-12 & -156 & 69 & 497 & 63 \\
Guyana & -8 & 492 & 271 & -24 \\
Central America/Caribbean & 55 & 2447 & 1028 & 73 \\
Zimbabwe & -4 & 79 & 38 & 146 \\
Mauritius & -13 & 537 & 320 & -11 \\
Swaziland & 35 & 562 & 246 & 23 \\
India & -39 & -17 & 167 & -28 \\
Mozambique & 65 & 5 & 3 & 5 \\
Malawi & 125 & 31 & 15 & 9 \\
Tanzania & 253 & 55 & 24 & -4 \\
Uganda & 6 & -2 & -3 & -2 \\
Zambia & 71 & 15 & 9 & 55 \\
Sub-Saharan Africa & 1552 & 212 & 53 & -56 \\
Bangladesh & -2 & -4 & -9 & -6 \\
Nepal & 1098 & 233 & 85 & -11 \\
Brazil & 137 & 106 & 799 & 4733 \\
Thailand & 23 & 33 & 96 & 23 \\
Australia & 31 & 32 & 120 & 31 \\
Rest of the World & -4 & -470 & 310 & -919 \\
\hline
\end{tabular}

\section{Conclusions}

Gradual changes within the tariff rate quotas in the EU sugar regime would have a very marginal impact on the flow of sugar exports to the EU appear and world sugar markets as well. The simulation results showed that the scheduled changes in tariff rate quotas and transition period are stalling the impacts of tariff liberalisation granted by the EBA concession. Small concessions will not threaten the EU internal market, but total liberalisation of sugar imports from the LDCs will be a major threat to the EU sugar regime. Conversely, the EU would gain from the liberalisation scenarios in welfare terms due to cheaper imports of sugar. The welfare effects are opposite compared to the trade effects in the case of the EU.

The current EU sugar regime limits sugar imports from all developing countries or some efficient producers, if the cost data is a right estimate of the potential supply response from developing countries. Under the trade liberalisation scenarios, Guyana would be one of the countries that would lose both in welfare and trade terms due to the loss of preferences. The LDCs would gain in market access due to the EBA concession, but much of the gains are diluted due to the deterioration in the terms of trade under the total liberalisation scenario. The LDCs would be the major winners under the 
EBA concession supported by the current regime, but a few efficient sugar producers will be the winners if the current regime is entirely liberalised for all countries.

The full liberalisation of the EU sugar regime and the abolition of the preferential treatment in the EU sugar regime would change the position of the countries as winners or losers. The assumptions on the production and export possibilities of the sugar producing countries and the homogenous nature of sugar would create more losers than winners. For some of the losers, the loss of sugar exports could seriously damage their fragile economy. Therefore, the abolition or loss of preferential treatment is an important issue and hotly debated around the world.

Trade preferences have the potential of helping developing countries to promote self-sustained economic development and can substitute transfers in the form of direct financial assistance from developed countries to poor developing countries. The EU has maintained this development perspective by granting preferential access to the highly protected and subsidised EU sugar market with prices significantly above the world market prices. In the short run, any sudden changes in the EU regime and trade policies may cause severe problems for the poor currently employed in the export-oriented sugar industry of the developing countries. Compensation is needed for these affected people because of the adjustment costs due to the changes in trade policies. In the long run, the sustainable export performance and economic development based on the comparative advantage of the developing countries should be the final objective. Though, the livelihood of the poor must be protected against sudden changes in trade policies in the effort to achieve the Millennium Development Goals.

\section{References}

Borrell, B. \& Pearce, D. 1999. "Sugar: The Taste Test of Trade Liberalisation." Centre for International Economics, Canberra \& Sydney.

Devadoss, S. \& Kropf, J. 1996. Impacts of trade liberalizations under the Uruguay Round on the world sugar market. Agricultural Economics 15: 83-96.

\section{F.O. Lichts International Sugar and Sweetener Report.}

Frandsen, S., Jensen, H., Wusheng Yu \& Walter-Jørgensen, A. 2003. Reform of EU sugar policy: price cuts versus quota reductions. European Review of Agricultural Economics 30: 1-26.

OECD 2003. Sugar policy reform in OECD countries: Stage I: An et-ante analysis of the impacts on world sugar markets of selected options for further trade liberalisation in OECD countries. Directorate for Food, Agriculture and Fisheries, Committee for Agriculture, Organisation for Economic Cooperation and Development, 23 October 2003. AGR/CA/APM(2003)23.

Poonyth, D., Westhoff, P., Womack, A. \& Adams, G. 2000. Impacts of WTO restrictions on subsidised EU sugar exports. Agricultural Economics 22: 233-245. 